\title{
TREATMENT USING REVERSE OSMOSIS OF AN EFFLUENT FROM STAINLESS STEEL MANUFACTURE
}

\author{
JAPIE J. SCHOEMAN*, ANDRÉ STEYN and PETER J. SCURR \\ Watertek, CSIR, P.O. Box 395, Pretoria 0001, South Africa
}

\begin{abstract}
Reverse osmosis (RO) and physical/chemical technology were evaluated for treatment of neutralized spent acid effluent (seepage) containing high concentration levels of TDS $(7500 \mathrm{mg} / \mathrm{l}), \mathrm{Ca}$ $(400 \mathrm{mg} / \mathrm{l}), \mathrm{Cr}^{\mathrm{VI}}(42 \mathrm{mg} / \mathrm{l})$, nitrate-nitrogen $(827 \mathrm{mg} / \mathrm{l})$, ammonia-nitrogen $(33 \mathrm{mg} / \mathrm{l})$, fluoride $(13 \mathrm{mg} /)$, phenolics $(45 \mathrm{mg} / \mathrm{l})$ and $\operatorname{COD}(620 \mathrm{mg} / \mathrm{l})$. The calcium concentration level in the seepage could be reduced from approximately 400 to $5 \mathrm{mg} / \mathrm{l}$ with soda ash softening. Initial permeate flux (feed and bleed system, $85 \%$ water recovery) was $278 \mathrm{l} / \mathrm{m}^{2} \cdot \mathrm{d}$. Permeate flux, however, dropped rapidly in the beginning of the run and then remained approximately constant to the end of the run. However, chemical cleaning of the membranes was necessary to maintain flux. The TDS of the RO feed could be reduced in one case from 34,253 to $1560 \mathrm{mg} / 1(95.5 \%$ removal) at $85 \%$ water recovery. Nitrate and ammonia nitrogen were reduced from 2691 and $103 \mathrm{mg} / \mathrm{l}$ to 414 ( $84.6 \%$ removal) and $15 \mathrm{mg} / 1$ (85.3\% removal), respectively. Chromium ${ }^{\mathrm{vi}}$ and fluoride were reduced from 183 and $90 \mathrm{mg} / 1$ to 0.38 (99.8\% removal) and $2.8 \mathrm{mg} / 1$ (96.9\% removal), respectively. COD removals varied between 60 and $80 \%$. No phenolics, however, could be removed from the feed (approximately $32 \mathrm{mg} / \mathrm{l}$ ) with the cellulose acetate RO membranes. Phenolics, however, could be effectively removed $(<0.2 \mathrm{mg} / \mathrm{l})$ from the RO permeate with hydrogen peroxide oxidation or ion-exchange treatment. Preliminary test work has shown that it should be possible to treat the seepage effectively with RO for pollution control, effluent volume reduction and water recovery. Capital costs for a $600 \mathrm{kl} / \mathrm{d}$ plant for lime softening, RO and oxidation equipment are estimated at U.S. $\$ 58,000$, U.S. $\$ 350,000$ and U.S. $\$ 87,500$, respectively. Copyright (C) 1996 Elsevier Science Ltd
\end{abstract}

Key words-neutralized spent acid, reverse osmosis, pollution control, permeate flux, chemical cleaning, nitrate-nitrogen removal, ammonia-nitrogen removal, chromium ${ }^{\mathrm{vI}}$ removal, phenolics removal, COD removal

\section{INTRODUCTION}

Hazardous effluent is produced by a stainless steel manufacturer in South Africa. Effluent originates as a result of metal pickling with nitric, sulphuric and hydrofluoric acids and coal gasification. The spent acid effluent is neutralized with lime and disposed of together with coal gasification liquor to evaporation ponds. This effluent has the potential to pollute ground water sources in the vicinity of the factory. The effluent contains high concentration levels of organics (including phenols) and other hazardous inorganics $\left(\mathrm{F}, \mathrm{NO}_{3}-\mathrm{N}, \mathrm{NH}_{3}-\mathrm{N}, \mathrm{Cr}\right)$ and is also almost saturated with calcium sulphate. Seepage of the effluent is taking place through the walls of the evaporation ponds which is intercepted in infiltration trenches below the ponds and returned to the ponds.

Reverse osmosis (RO) technology has been investigated (Krug and McDougall, 1989; Chian and de Walle, 1976; Slater et al., 1983; Whittaker et al., 1988; Weber and Holz, 1991) and is applied (Weber

*Author to whom all correspondence should be addressed [Fax: (27) 128414785$]$. and Holz, 1991; Peters, 1994) for treatment of municipal leachate. Reverse osmosis has also been evaluated for treatment of coal gasification liquors (Williams, 1991). Tubular (Weber and Holz, 1991) and disc tube RO (Peters, 1994) are successfully applied for the treatment of municipal leachate for TDS, COD and ammonia-nitrogen removals. It appears from the literature that tubular RO can be successfully applied for treatment of coal gasification liquors for TDS, COD and ammonia-nitrogen removals (Williams, 1991). The hazardous cffluent produced by the stainless steel manufacturer has similar characteristics (high TDS, COD and ammonia-nitrogen levels) as municipal leachate. Consequently, it was decided to evaluate RO for treatment of the industrial leachate.

Preliminary studies in the laboratory have indicated that it should be possible to treat the effluent successfully with soda ash softening followed by RO desalination. However, membrane fouling by organics in the effluent may lead to process failure. Poor rejection of organics by RO membranes may also make the process unsuitable for pollution control. Consequently, it was necessary to evaluate physical/ 


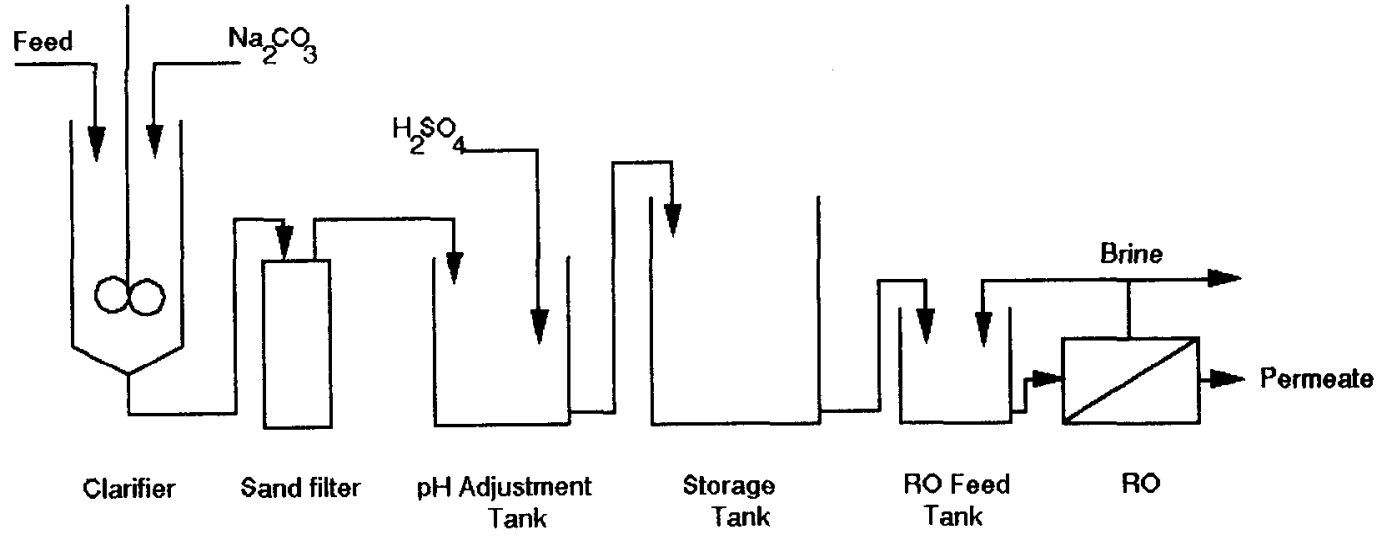

Fig. 1. Pilot plant setup.

chemical and membrane technologies for effluent treatment through pilot studies to develop process design criteria for a full-scale application.

The objectives of the study were to: (1) evaluate physical/chemical and membrane technology for treatment of the effluent; (2) develop process design criteria for a full-scale plant; and (3) determine the economics of the process.

\section{EXPERIMENTAL}

\section{Process description}

The pilot plant set-up is shown in Fig. 1. Seepage from the infiltration trenches was pumped into a $1.7 \mathrm{~m}^{3}$ clarifier/thickener. Soda ash $(2.6 \mathrm{~kg})$ was used for water softening. The partial clarified softened effluent was sandfiltered and stored in a 1 kilolitre storage tank where the $\mathrm{pH}$ of the effluent (approximately 10) was reduced to approximately 6.5 with concentrated sulphuric acid ( 150 to $450 \mathrm{ml}$ concentrated acid per $\mathrm{kl}$ effluent). The $\mathrm{pH}$ adjusted effluent was pumped into a $5 \mathrm{kl}$ storage tank and this water was used as feed to the RO unit.

The RO unit contained two tubular cellulose acetate membrane modules ( $3.5 \mathrm{~m}^{2}$ area). Sponge ball cleaning with flow reversal was applied every $60 \mathrm{~min}$. The level of the feedwater (approximately $200 \mathrm{l}$ ) in the RO tank was kept constant with a level controller. Brine was circulated back to the feed tank and runs were conducted at approximately 50 and $85 \%$ water recovery to study the fouling potential of the effluent for the RO membranes. Feed pressure was kept at $4000 \mathrm{kPa}$. Permeate flux (corrected to $25^{\circ} \mathrm{C}$ ), brine flow rate, pressures, $\mathrm{pH}$, conductivities of the $\mathrm{RO}$ feed, permeate and brine, were measured at regular intervals. The chemical composition of the effluent, softened effluent, $\mathrm{pH}$ adjusted effluent, RO feed, permeate and brine, were also determined at regular intervals.

\section{Membrane cleaning}

Biotext $(0.5 \%)$, citric acid $(2 \% ; \mathrm{pH} 4.5)$, EDTA $(0.5 \%$ $\mathrm{pH} 10)$ and P3 Ultrasil $50(0.5 \%)$ were evaluated for membrane cleaning. Cleaning agent was circulated through the membrane modules at reduced pressure for one hour followed by a tap water rinse for $30 \mathrm{~min}$. Clean water fluxes were measured before and after cleaning.

\section{Treatment of $R O$ permeate with ion-exchange}

Reverse osmosis permeate was treated with Amberlite XAD-4 resin in a glass column $(16.5 \mathrm{~mm}$ diameter, one bed volume (BV) equal to $85 \mathrm{~cm}^{3}$ ). Loading was conducted at $5 \mathrm{BV} / \mathrm{h}$. Phenol in the column effluent was determined colorimetrically and with high-pressure liquid chromatog- raphy. The resin was regenerated with $5 \mathrm{BVs}$ methanol at a flow rate of $8 \mathrm{BV} / \mathrm{h}$.

Phenol oxidation with hydrogen peroxide

The $\mathrm{pH}$ of $11 \mathrm{RO}$ permeate was reduced to 4 with sulphuric acid. $10 \mathrm{mg} / 1$ ferrous iron was added to the samples and different molar ratios of $\mathrm{H}_{2} \mathrm{O}_{2}(30 \%)$ to phenol were added to the samples which were stirred for $30 \mathrm{~min}$. The samples were filtered and phenol and COD analyses were conducted.

\section{RESULTS AND DISCUSSION}

Chemical composition of effluent and pretreated effluent

A typical composition of the leachate, leachate after softening with soda ash and $\mathrm{pH}$-adjusted effluent is shown in Table 1.

The electrical conductivity of the leachate is high. The leachate is also approximately saturated with calcium sulphate. The leachate also contains high concentration levels of hazardous chemicals like

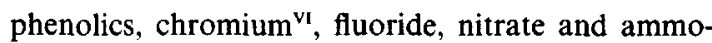
nia-nitrogen.

Table 1. Chemical composition of leachate, softened and $\mathrm{pH}$ adjusted efluent

\begin{tabular}{|c|c|c|c|}
\hline $\begin{array}{l}\text { Constituents } \\
(\mathrm{mg} / \mathrm{l})\end{array}$ & Leachate & $\begin{array}{c}\text { Softened } \\
\text { effluent }\end{array}$ & $\begin{array}{c}\text { pH adjusted } \\
\text { effluent }\end{array}$ \\
\hline COD & 620 & 600 & 520 \\
\hline TKN & 66.9 & 48.4 & 41 \\
\hline Ammonia-nitrogen & 32.9 & 39.1 & 41.6 \\
\hline Nitrate-nitrogen & 826.5 & 815.1 & 860.1 \\
\hline Alkalinity & 145 & 907 & 207 \\
\hline Iron & 0.15 & 0.06 & 0.07 \\
\hline Chromium & 43.8 & 40.40 & 34.30 \\
\hline Sodium & 1223 & 1543 & 1719 \\
\hline Potassium & 906 & 827 & 771 \\
\hline Calcium & 400 & 5 & 12 \\
\hline Magnesium & 6 & 2 & 9 \\
\hline Sulphate (total) & 1327 & 1324 & 1706 \\
\hline Chloride & 717 & 671 & 671 \\
\hline Phenolics & 44.89 & 42.2 & 37.95 \\
\hline Manganese & 0.040 & $<0.025$ & $<0.025$ \\
\hline Nickel & 0.060 & 0.040 & 0.040 \\
\hline Chromium $^{\mathrm{VI}}$ & 42 & 40 & 34 \\
\hline Fluoride & 12.6 & 11.6 & 11.9 \\
\hline Conductivity (mS/m) & 602 & 617 & 634 \\
\hline TDS & 7421 & 7865 & 7192 \\
\hline pH & 11.3 & 11.27 & 6.62 \\
\hline
\end{tabular}




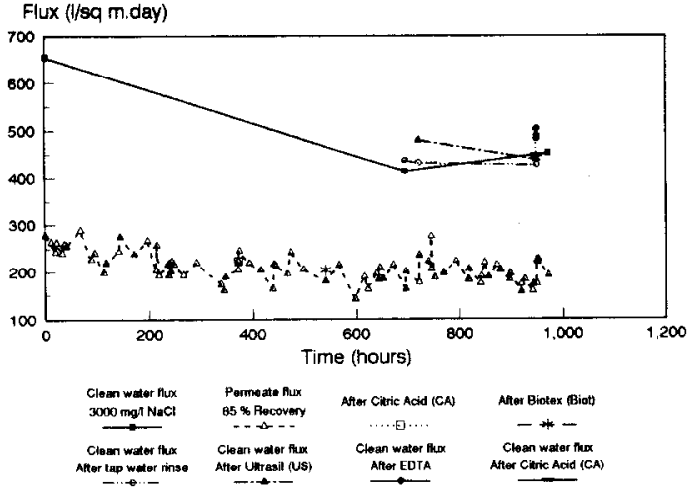

Fig. 2. Permeate flux as a function of time at $85 \%$ water recovery.

Calcium could be removed effectively from the effluent with soda ash softening. However, the sodium and alkalinity levels of the softened water were significantly increased with soda ash addition. The sulphate concentration level of the pH-adjusted effluent was also significantly increased after sulphuric acid addition to lower the $\mathrm{pH}$ to less than 7 prior to RO treatment.

\section{Permeate flux as a function of time}

Permeate flux as a function of time at $85 \%$ water recovery is shown in Fig. 2. Permeate flux declined fairly rapidly at the beginning of the run and then appeared to remain approximately constant at the end of the run. However, some decline in permeate flux was observed. Permeate flux was determined at $2781 / \mathrm{m}^{2} \cdot \mathrm{d}$ when the run was commenced. Permeate flux, however, dropped to $243 \mathrm{l} / \mathrm{m}^{2} \cdot \mathrm{d}$ after $5 \mathrm{~h}$ of operation. This drop in permeate flux could be ascribed to surface fouling of the membranes. Permeate flux declined further and was measured at $205 \mathrm{l} / \mathrm{m}^{2} \cdot \mathrm{d}$ after $372 \mathrm{~h}$ of operation. The membranes were now for the first time cleaned and cleaning with citric acid increased permeate flux to $224 \mathrm{l} / \mathrm{m}^{2} \cdot \mathrm{d}$. Flux again decreased and was determined at $180 \mathrm{l} / \mathrm{m}^{2} \cdot \mathrm{d}$ after $540 \mathrm{~h}$ of operation. Cleaning of the membranes with a Biotex solution increased permeate flux to $203 \mathrm{l} / \mathrm{m}^{2} \cdot \mathrm{d}$. Permeate flux again decreased and was determined at $1761 / \mathrm{m}^{2} \cdot \mathrm{d}$ after $722 \mathrm{~h}$ of operation. The membranes were cleaned with P3 Ultrasil 50 cleaning agent and permeate flux was measured at $235 \mathrm{l} / \mathrm{m}^{2} \cdot \mathrm{d}$ after $722 \mathrm{~h}$ of operation. Permeate flux again decreased and was determined at $1731 / \mathrm{m}^{2} \cdot \mathrm{d}$ after $950 \mathrm{~h}$ of operation. The membranes were then cleaned with Ultrasil, citric acid and EDTA $(2 \times$, $\mathrm{pH}$ 10). Permeate flux was determined at $225 \mathrm{l} / \mathrm{m}^{2} \cdot \mathrm{d}$ when the run was commenced. Permeate flux was measured at $1911 / \mathrm{m}^{2} \cdot \mathrm{d}$ when the run was terminated after $972 \mathrm{~h}$ of operation.

Clean water flux $(3000 \mathrm{mg} / 1 \mathrm{NaCl})$ was measured at $650 \mathrm{l} / \mathrm{m}^{2} \cdot \mathrm{d}$ when the run was commenced. Clean water flux $(3000 \mathrm{mg} / \mathrm{l} \mathrm{NaCl})$ was determined at 414 (after $695.5 \mathrm{~h}$ ) and $454 \mathrm{l} / \mathrm{m}^{2} \cdot \mathrm{d}$ when the run was terminated after $972 \mathrm{~h}$ of operation. This showed that a certain degree of irreversible membrane fouling had taken place or that the membranes were not completely cleaned with chemical cleaning. More frequent cleaning, however, should give better results.

Clean water flux with tap water was determined at $437 \mathrm{l} / \mathrm{m}^{2} \cdot \mathrm{d}$ after $695.5 \mathrm{~h}$ of operation. Clean water flux decreased slightly to $4331 / \mathrm{m}^{2} \cdot \mathrm{d}$ after $722 \mathrm{~h}$ of operation. However, clean water flux increased significantly to $480 \mathrm{l} / \mathrm{m}^{2} \cdot \mathrm{d}$ after the membranes were cleaned with Ultrasil cleaning agent. Clean water flux, however, decreased to $428 \mathrm{l} / \mathrm{m}^{2} \cdot \mathrm{d}$ after $950 \mathrm{~h}$ of operation. Cleaning of the membranes with Ultrasil cleaning agent increased the clean water flux to $4411 / \mathrm{m}^{2} \cdot \mathrm{d}$. Therefore, it appeared that the clean water flux could not be restored to the level of $480 \mathrm{l} / \mathrm{m}^{2} \cdot \mathrm{d}$ that was obtained after the previous cleaning with Ultrasil cleaning agent. Cleaning of the membranes with citric acid increased the clean water flux to $450 \mathrm{l} / \mathrm{m}^{2} \cdot \mathrm{d}$. This increase in permeate flux, however, was not very significant. Further cleaning of the membranes with EDTA $(2 \times, \mathrm{pH} 10)$ increased the clean water flux to 483 and $5041 / \mathrm{m}^{2} \cdot \mathrm{d}$. Therefore, it appeared that it should be possible to control membrane fouling with regular chemical cleanings.

It is further interesting to note that permeate flux has increased significantly after tap water rinses. Tap water rinses were conducted every day for $30 \mathrm{~min}$ at reduced pressure. Permeate flux, for example, increased from 162 to $201 \mathrm{l} / \mathrm{m}^{2} \cdot \mathrm{d}$ after a water rinse (696 h of operation).

Conductivity of the RO feed, permeate and brine as a function of time

Conductivity of the RO feed, permeate and brine as a function of time is shown in Fig. 3. The conductivity of the RO feed varied between 1500 and $2600 \mathrm{mS} / \mathrm{m}$ over the test period. Brine conductivity was only slightly higher than that of the feed because brine was recirculated back to the feed tank Permeate conductivity varied between 55 and $245 \mathrm{mS} / \mathrm{m}$ over the test period.

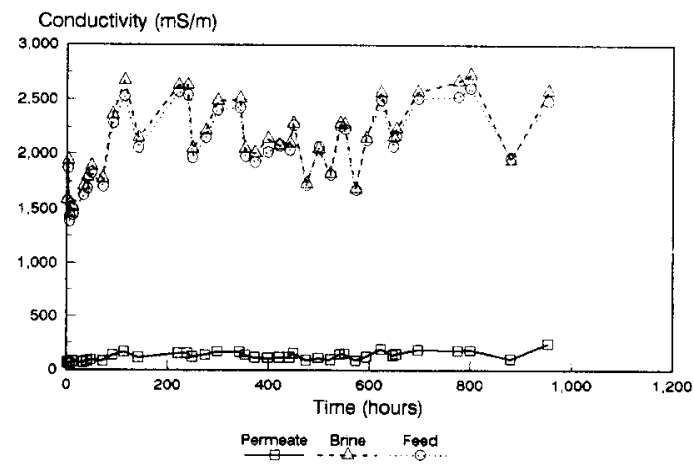

Fig. 3. Conductivity of RO feed, permeate and brine as a function of time at $85 \%$ water recovery. 


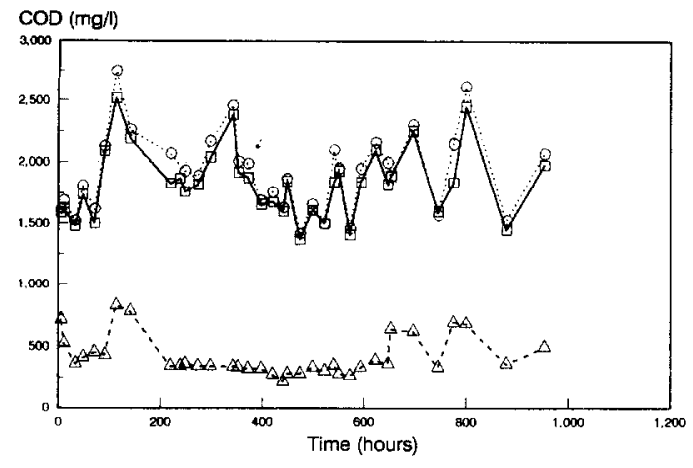

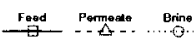

Fig. 4. COD of RO feed, permeate and brine as a function of time at $85 \%$ water recovery.

Chemical oxygen demand (COD) of the RO feed, permeate and brine as a function of time

The chemical oxygen demand of the RO feed, permeate and brine as a function of time is shown in Fig. 4. The COD of the RO feed varied between 1500 and $2500 \mathrm{mg} / 1$. The COD of the brine was also only slightly higher than that of the RO feed. COD of the RO permeate varied between approximately 800 and $250 \mathrm{mg} / \mathrm{l}$ over the test period. This showed that a significant amount of organics in the RO feed were not removed by the cellulose acetate RO membranes.

Conductivity, COD rejection and percentage water recovery as a function of time

The conductivity, COD rejection and percentage water recovery as a function of time are shown in Fig. 5. Water recovery was kept at approximately $85 \%$ for the entire run. Conductivity rejection varied between 90 and $95 \%$. Conductivity rejection remained approximately constant for more than $800 \mathrm{~h}$ of operation. This showed that serious membrane fouling was not experienced. COD rejection varied between approximately 60 and $80 \%$. Therefore, relatively poor organic removals were obtained.

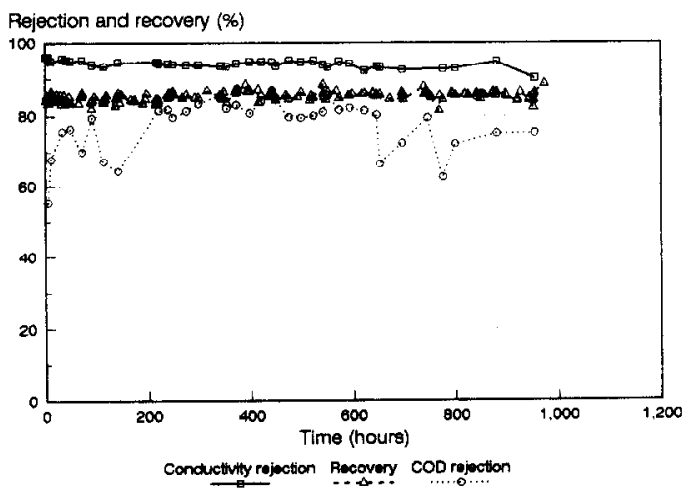

Fig. 5. Conductivity, COD rejection and percentage water recovery.
Chemical composition of $R O$ feed, permeate and brine

An example of the chemical composition of the RO feed, permeate and brine is shown in Table 2. Excellent conductivity $(93.5 \%)$ and TDS $(95.5 \%)$ removals were obtained. Chromium ${ }^{\text {vi }}$ could be reduced from 183 to $0.38 \mathrm{mg} / 1$ ( $99.8 \%$ removal). Fluoride could be removed from 90 to $2.8 \mathrm{mg} / \mathrm{l}$ (96.9\% removal). COD was removed from 1840 to $350 \mathrm{mg} / 1$ ( $81.0 \%$ removal). However, poor phenolics removal was obtained. It appeared that no phenolics removal was obtained with RO.

\section{Phenolics removal with ion exchange}

Removal of phenolics from the RO permeate with ion exchange is shown in Table 3. Phenolics in the RO permeate $(68 \mathrm{mg} / \mathrm{l})$ could be reduced to approximately $0.01 \mathrm{mg} / \mathrm{l}$. Approximately $80 \mathrm{BVs}$ water with a low concentration level of phenolics could be obtained.

\section{Phenolics removal with hydrogen peroxide}

Removal of phenolics from the RO permeate with hydrogen peroxide oxidation is shown in Table 4. Phenolics could be effectively removed from the RO permeate with hydrogen peroxide oxidation. A $99.7 \%$ removal of phenolics could be obtained with a hydrogen peroxide dosage of $285 \mathrm{mg} / \mathrm{l}$. Phenolics were removed from $52.3 \mathrm{mg} / \mathrm{l}$ in the RO permeate to $0.16 \mathrm{mg} / \mathrm{l}$ in the treated water. However, it appears that it will not be possible to reduce the phenolics concentration to much lower levels.

Organics could also be effectively removed with hydrogen peroxide. COD was removed from 420 to $72 \mathrm{mg} / 1(82.8 \%$ removal $)$ at a hydrogen peroxide dosage of $648 \mathrm{mg} / \mathrm{l}$.

\section{Economics}

A preliminary estimate of capital and operational cost to treat $600 \mathrm{kl} / \mathrm{d}$ effluent is shown in Table 5 .

The capital and operational costs shown in Table 5 are a preliminary estimate of the cost that will be involved to treat $600 \mathrm{kl} / \mathrm{d}$ effluent. A more accurate estimate of cost involved can be obtained from a detailed design of the process to treat the effluent.

\section{CONCLUSIONS}

It appears that industrial seepage produced by a stainless steel manufacturer can be effectively treated with RO, oxidation $\left(\mathrm{H}_{2} \mathrm{O}_{2}\right)$ or ion exchange for pollution control, effluent volume reduction and water recovery. Oxidation or ion-exchange treatment of the RO permeate will be necessary to reduce phenolics in the effluent (approximately $50 \mathrm{mg} / \mathrm{l}$ ) to low concentration levels $(<0.2 \mathrm{mg} / \mathrm{l})$. Water recovery of $85 \%$ should be possible. A steady decline in RO 
Table 2. Chemical composition of RO feed, permeate and brine ( $85 \%$ recovery)

\begin{tabular}{lcccc}
\hline $\begin{array}{l}\text { Constituents } \\
\text { (mg/l) }\end{array}$ & Feed & Brine & Permeate & $\begin{array}{c}\text { Rejection } \\
\text { (\%) }\end{array}$ \\
\hline COD* & 1840 & 2100 & 350 & 80.98 \\
TKN† & 111.8 & 137.2 & 26.6 & 76.21 \\
Ammonia-nitrogen & 102.6 & 104.2 & 15.1 & 85.28 \\
Nitrate-nitrogen & 2691.1 & 2772.4 & 413.8 & 84.62 \\
Alkalinity & 886 & 994 & 116 & 86.91 \\
lron & 0.72 & 0.73 & $<0.03$ & 95.83 \\
Chromium (total) & 183 & 184 & 0.58 & 99.68 \\
Sodium & 8314 & 8490 & 309 & 96.28 \\
Potassium & 3646 & 3915 & 185 & 94.93 \\
Calcium & 75 & 81 & 2 & 97.33 \\
Magnesium & 38 & 43 & 1 & 97.37 \\
Sulphate (total) & 4402 & 6696 & 557 & 87.35 \\
Chloride & 3366 & 3473 & 82 & 97.56 \\
Phenolics & 32.17 & 32.17 & 48.63 & \\
Manganese & 0.09 & 0.09 & $<0.025$ & 72.22 \\
Nickel & 0.31 & 0.32 & $<0.025$ & 91.94 \\
Chromium & 183 & 92.5 & 0.38 & 99.79 \\
Fluoride & 90 & 2290 & 2.8 & 96.89 \\
Conductivity (mS/m) & 2260 & 35,352 & 146 & 93.54 \\
TDS & 34253 & 7.38 & 1560 & 95.45 \\
pH & 7.37 & 6.28 & \\
\hline
\end{tabular}

${ }^{*} \mathrm{COD}=$ chemical oxygen demand, $+\mathrm{TKN}=$ total $\mathrm{Kjeldahl} \mathrm{nitrogen}$.

permeate flux, however, was observed as a function of time. However, it appears that it should be possible to control membrane fouling with chemical cleaning. A preliminary estimate has shown that a membrane lifetime of approximately 3 yr can be expected.

Excellent conductivity removals were obtained at $85 \%$ water recovery. Conductivity of the RO feed varied between 1500 and $2600 \mathrm{mS} / \mathrm{m}$. Permeate conductivity varied between 55 and $245 \mathrm{mS} / \mathrm{m}$. Conductivity rejection between 90 and $95 \%$ was obtained.

Relatively good COD removals were obtained at $85 \%$ water recovery. COD of the RO feed varied between 1500 and $2500 \mathrm{mg} / \mathrm{l}$. COD of the RO permeate varied between 250 and $800 \mathrm{mg} / \mathrm{l}$. COD rejection between 60 and $80 \%$ was obtained.

Excellent calcium removals were obtained with soda ash softening. Calcium was removed in one case from $400 \mathrm{mg} / \mathrm{l}$ in the feed to $5 \mathrm{mg} / 1$ in the treated water.

Excellent chromium, fluoride, manganese, nitrate and ammonium nitrogen removals were obtained at $85 \%$ water recovery. Chromium ${ }^{\text {VI }}$ was in one case removed from $183 \mathrm{mg} / \mathrm{l}$ in the RO feed to $0.38 \mathrm{mg} / \mathrm{l}$ in the RO permeate ( $>99 \%$ removal). Fluoride and manganese were removed from 90 to $2.8 \mathrm{mg} / 1$ ( $96.9 \%$ removal) and 0.09 to $<0.025 \mathrm{mg} / \mathrm{l}$, respectively. Nitrate-nitrogen and ammonia-nitrogen were removed from 2691 to $414 \mathrm{mg} / 1$ (84.6\% removal) and 103 to $15 \mathrm{mg} / \mathrm{l}(85.3 \%$ removal $)$, respectively. Phenolics, however, were poorly rejected by the cellulose acetate RO membranes.

Phenolics could be effectively removed from the RO permeate with ion exchange. Phenolics could be removed from $68 \mathrm{mg} / 1$ to less than $0.1 \mathrm{mg} / 1$.

Phenolics could also be effectively removed from the RO permeate with hydrogen peroxide oxidation. Phenolics were removed from $52 \mathrm{mg} / \mathrm{l}$ in the RO permeate to approximately $0.1 \mathrm{mg} / 1$ in the treated water. COD in the RO permeate could also be significantly reduced with hydrogen peroxide oxidation (from 420 to $72 \mathrm{mg} / \mathrm{l}$ ).

Capital costs for lime softening, RO and oxidation equipment are estimated at U.S. $\$ 58,000$, U.S. $\$ 350,000$ and U.S. $\$ 87,500$, respectively. The operational cost for softening is estimated at U.S. $\$ 0.47 / \mathrm{kl}$. Reverse osmosis and hydrogen peroxide oxidation operational costs are estimated at U.S. $\$ 0.47 / \mathrm{kl}$ and U.S. $\$ 0.50 / \mathrm{kl}$, respectively.

Table 4. Phenolics and COD removal with hydrogen peroxide oxidation

Table 3. Phenolics concentration in ionexchange product water as a function of bed-volumes of RO permeate passed through the column $(1 \mathrm{BV}=85 \mathrm{ml})$

\begin{tabular}{cc}
\hline & $\begin{array}{c}\text { Phenolics concentration } \\
\text { BVs }\end{array}$ \\
\hline 0 & 68.0 \\
20 & 0.03 \\
40 & 0.01 \\
60 & 0.01 \\
80 & 0.01 \\
100 & \\
120 & 1.47 \\
140 & 24.7 \\
\hline
\end{tabular}

\begin{tabular}{lccccc}
\hline $\begin{array}{c}\mathrm{Mol} \mathrm{H}_{2} \mathrm{O}_{2} \\
\text { Mol Phenol }\end{array}$ & $\begin{array}{c}\mathrm{H}_{2} \mathrm{O}_{2} \\
(\mathrm{mg} / \mathrm{l})\end{array}$ & $\begin{array}{c}\text { Phenolics* } \\
(\mathrm{mg} / \mathrm{l})\end{array}$ & $\begin{array}{c}\% \\
\text { Removal }\end{array}$ & $\begin{array}{c}\mathrm{COD}^{*} \\
(\mathrm{mg} / \mathrm{l})\end{array}$ & $\begin{array}{c}\% \\
\text { Removal }\end{array}$ \\
\hline 4 & 81 & 29.41 & 43.8 & 340 & 19 \\
8 & 162 & 15.48 & 70.4 & 360 & 14.3 \\
10 & 201 & 2.22 & 95.7 & 191 & 54.5 \\
12 & 243 & 0.36 & 99.3 & 164 & 60.1 \\
14 & 285 & 0.16 & 99.7 & 168 & 60 \\
16 & 324 & 0.16 & 99.7 & 142 & 66.2 \\
18 & 363 & 0.11 & 99.8 & 112 & 73.3 \\
20 & 402 & 0.10 & 99.8 & 112 & 73.3 \\
22 & 441 & 0.12 & 99.8 & 85 & 79.8 \\
32 & 648 & 0.15 & 99.7 & 72 & 82.8 \\
\hline "Initial phenolics and COD concentrations were 52.3 and $420 \mathrm{mg} / 1$, \\
respectively.
\end{tabular}


Table 5. Capital and operational cost (preliminary estimate) to treat $600 \mathrm{kl} / \mathrm{d}$ effluent

\begin{tabular}{lcc}
\hline Item & $\begin{array}{c}\text { Capital cost } \\
\text { (U.S.\$) }\end{array}$ & $\begin{array}{c}\text { Operational cost } \\
\text { (U.S.\$) }\end{array}$ \\
\hline $\begin{array}{l}\text { Clarifier/thickener } \\
\text { (softening) }\end{array}$ & 58,300 & 0.47 \\
RO unit & 350,000 & 0.47 \\
Oxidation & 87,500 & 0.50 \\
\hline
\end{tabular}

\section{REFERENCES}

Chian E. S. and de Walle F. B. (1976) Sanitary landfill leachates and their treatment. Am. Soc. Civil Eng., Environ. Eng. Div. J. 102 (EE2), 411-431.

Krug T. A. and McDougall S. (1989) Preliminary Assessment of a Microfiltration/Reverse Osmosis Process for the Treatment of Landfill leachate. Zenon Environmental, Inc. Burlington, Ontario, Canada. Proceedings of the 43rd Industrial Waste Conference, May 10-12 1988. Purdue University, West Lafayette, Indiana 43, 185-193.
Peters T. A. (1994) Treatment of landfill leachate by conventional and high pressure reverse osmosis based on the disc tube module. In Engineering of Membrane Processes 11, Environmental Applications, 26-28 April 1994, 11 Ciocco, Tuscany; Italy.

Slater S. C., Ahlert R. C. and Uchrin C. G. (1983) Treatment of landfill leachates by reverse osmosis. Environ. Progr. 2, 251-256.

Weber B. and Holz F. (1991) Landfill leachate treatment by reverse osmosis. In Effective Industrial Membrane Processes: Benefits and Opportunities (Edited by Turner M. K.). Elsevier Science Publishers Ltd., Barking, Essex. Whittaker H., Adams C. I., Salo S. A. and Morgan A. (1985) Reverse osmosis at the Gloucester Landfill. Proceedings of the Technical Seminar on Chemical Spills. Environment Canada, pp. 190-207.

Williams A. R. (1991) The use of reverse osmosis for the purification of coal gasification liquors. In Effective Industrial Membrane Processes: Benefits and Opportunities (Edited by Turner M. K.). Elsevier Science Publishers Ltd., Barking, Essex. 